\title{
Insects and arachnids of Ardeer, North Ayrshire, Scotland
}

\author{
B. Philp ${ }^{1}$, I. Hamlin ${ }^{2} \&$ A. Lavery ${ }^{3}$ \\ 17 Glebe Crescent, Ochiltree KA182QP \\ 216 Highfield Drive, Stevenston KA203AU \\ ${ }^{3}$ Burach, Carnbo, Kinross KY130NX \\ ${ }^{1}$ E-mail: brucephilp47@gmail.com
}

\begin{abstract}
The Ardeer site on the Garnock Estuary in North Ayrshire, Scotland is considered to be the richest wildlife site in Ayrshire and to be of national significance. It has a rich and varied invertebrate fauna which reflects the wide range of habitats present ranging from sand dunes to wetland and woodland. This paper gives an account of some of the insects and arachnids that have been discovered there during recent surveys. A number of current threats are outlined.
\end{abstract}

\section{INTRODUCTION}

In a previous paper the insect fauna of the Ardeer area was mentioned as part of a wider review of sand dune sites in Ayrshire (Philp \& Hamlin, 2016). Subsequent survey work has shown that the site is much richer than previously known and this paper outlines some new discoveries and discusses their importance, as well as providing greater detail on the importance of the whole site.

This importance has been thrust into greater prominence by recent media coverage outlining an anomaly in the planning system and the effect it is having on the site's biodiversity. In 1953 the U.K. Government passed a Special Development Order which effectively removed the requirement for planning permission for developments on the site. This has resulted in developments taking place that have bypassed the normal scrutiny of the planning process and have damaged the wildlife interest. Current "regeneration" proposals that could exploit this anomalous situation are being developed through the Ayrshire Growth Deal and threaten to cause further large-scale damage to the site.

\section{HISTORY}

The Ardeer site lies on either side of the estuary of the River Garnock, which is itself a SSSI, as it flows down towards Irvine, in North Ayrshire, Scotland (Fig. 1). The terrestrial part can be divided into four areas, one of which contains the core area of active industry and which has not been surveyed in any detail. The other three areas have been subject to ongoing survey work since 2010.

Geological maps reveal almost all of the peninsula to be underlain by windblown sand. The earliest OS maps

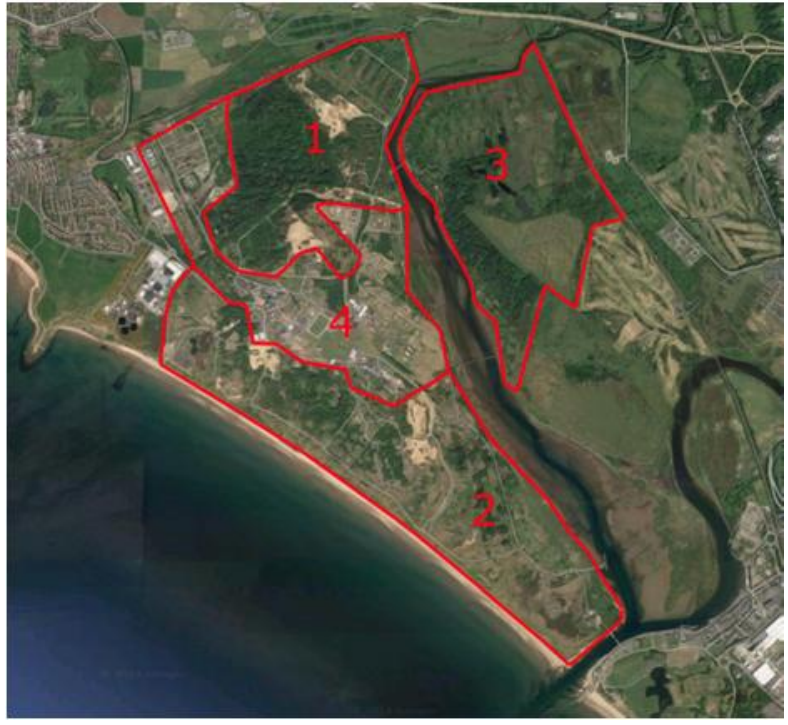

Fig. 1. Ardeer, North Ayshire, Scotland. Areas mentioned in the text: 1 - Garnock West (Black Powder Wood); 2 - Ardeer Peninsula; 3 - Garnock East; 4 - Industrial area. (Map data @ 2019 Google)

depict an extensive, largely undeveloped sand dune system, approximately $5 \mathrm{~km}$ in length and just over $2 \mathrm{~km}$ at its broadest (Ordnance Survey, 1856). Many of the sand dunes were over $15 \mathrm{~m}$ tall, with the tallest recorded being just over $27 \mathrm{~m}$. Early references to "a sand desert" (Nobel, 1871, in Dolan \& Oglethorpe, 1996) and an extensive plain that "exhibits a waste and dreary prospect of land, which blows in some places, and is prevented only by the deep-rooted bent growing through it, from being reduced to a dead level" (Woodrow, 1793) suggest a mobile dune system. Further evidence for the dynamism of the dunes comes from contemporary accounts of the sand covering crops and settlements further inland (Clements, 1974) and descriptions of the difficulty involved in stabilising the dunes during the late Victorian era (Trotter, 1938).

The earliest OS maps suggest saltmarsh covered extensive areas at the eastern edge of the peninsula, with some of the saltmarsh appearing to have been used as saltings (meadows subject to inundation by the sea). The more easterly area, marked on the map as Garnock East, has a long history of cultivation, with several farms 
being present at the site as far back as the earliest maps (Pont, in Blaeu, 1654).

The site changed dramatically in the years following 1871 as Alfred Nobel established and then built up his explosives works, eventually making it the largest explosives factory in the world. At its peak it employed around 13,000 workers and the site extended to over 500 ha. It was strategically important as a manufacturer of explosives during both World Wars and was a major employer in North Ayrshire. The company eventually became part of ICI and expanded its research and production to include artificial fibres, paints and many other products. Production declined throughout the late 20 th century and the former factory now persists only as a small energetics factory employing a few hundred people (Dolan \& Oglethorpe, 1996).

This very brief history appears to outline the familiar story of a natural habitat being replaced by a factory with a consequent loss of its wildlife value. However, in this case the relationship between industrial development and biodiversity is more complex. Although development destroyed significant areas of habitat, most of the buildings were, for safety reasons, spaced very far apart, leaving much habitat relatively intact. Furthermore, the exclusive use of the land as a factory effectively protected much of the site from golf and housing developments like those that have destroyed most of Ayrshire's other sand dune habitats. Furthermore, some industrial developments created new, interesting habitats. For example, the creation of fire ponds at Garnock East resulted in a 150 ha mosaic of wetland habitats, extensive tree planting created one of the largest woods in the county, and post-industrial remediation activities created large areas of bare sand and artificial dune slacks.

This all helped to diversify the range of habitats present and, following the closure of the site, most of the remaining land outwith the industrial estate has been largely left to develop without further disturbance.

However, the Special Development Order mentioned above has allowed large-scale sand quarrying at four locations in the north of the site, causing considerable damage (Fig. 2). As this has not required formal planning permission, there have not been impact assessments, or mitigation or restoration plans.

\section{HABITATS}

A broad range of "soft" coastal habitats is present at the southern part of Ardeer (the peninsula) ranging from sandy beach, embryo dunes, saltmarsh and mudflats through mobile dunes, fixed dunes, dune heath, dune slacks and dune scrub (Fig. 3). All of these have to some extent been altered by past and current management activities. For example, many of the tall fixed dunes are being targeted by the current quarrying operations and the extent of the mobile dunes is limited by the sea wall, although this is currently crumbling in places, especially at the southern end. The area supports the largest area of acid dune grassland in the U.K. (Dargie, 2000) and also one of the largest dune-spit systems (Dargie 1998).

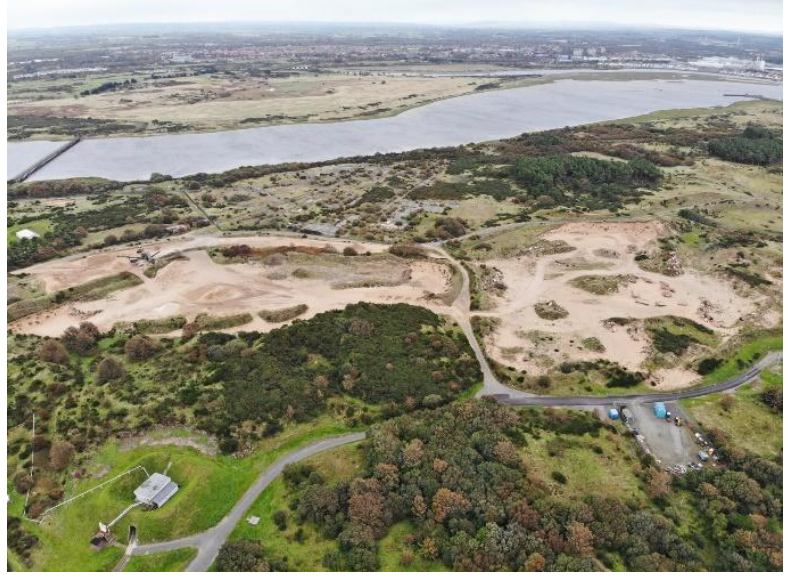

Fig. 2. Sand extraction in Garnock West, Ardeer, North Ayrshire, Scotland. (Photo: I. Hamlin)

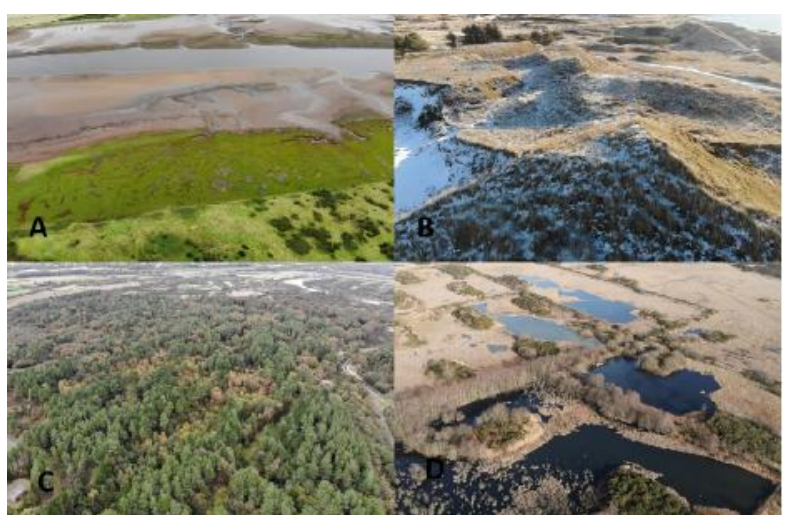

Fig. 3. Ardeer habitats, North Ayrshire, Scotland: A Saltmarsh; B - Fixed dunes; C - Black Powder Wood (Garnock West); D - Garnock East. (Photos: I. Hamlin)

All of these habitats have to some extent been altered by past and current management activities. For example, industrial earthworks reshaped dunes into tall blast walls and embankments, providing many areas of dune grassland with a hot, calm microclimate ideal for thermophilic invertebrates. Industrial excavations down to the water table created a diverse array of freshwater wetlands across the peninsula: dune slacks, swamp, marshy grassland, ephemeral pools and large, wellvegetated ponds with much open water.

The Ardeer site is also one of the most heavily wooded areas in North Ayrshire. It supports numerous large, over-mature conifer plantations which were planted in the mid 20th century and consist mainly of Corsican pine (Pinus nigra). They have been subject to little recent management and consequently contain significant amounts of dead wood. Over the decades, broadleaved species have colonised and the pines are, in places, greatly outnumbered by birches (Betula spp.), willows (Salix spp.), alder (Alnus glutinosa) and sycamore (Acer pseudoplatanus). Outside of the pine plantations, numerous areas of semi-natural woodland 
have established. In total, the peninsula supports over 100 ha of woodland.

The Garnock East portion of the site is quite different. Here the site is dominated by an extensive mosaic of fen, swamp, open water, scrub and woodland. The coastal influence is still evident with small areas of saltmarsh lining the western fringe of the site and relict areas of dune heath surviving in the east on ancient windblown sand deposits.

There is very little information about the wildlife of the site during its industrial period. Explosives works are inherently dangerous and access was not allowed while the site was in operation. With no tradition of visiting the site, it was used very little by the local population and, apart from visits by birdwatchers to the mudflats, no wildlife surveys were conducted.

From around 2009 I.H. started to look at the Hymenoptera on the site and it became clear that as well as several interesting and uncommon species being present, other groups such as hoverflies and beetles were well represented. Since then there has been more intensive survey work, which has reinforced the belief that Ardeer is of considerable importance for its invertebrate fauna.

Over the past ten years the survey effort has increased. In 2014 Buglife carried out a general survey of parts of Garnock West (Shanks, 2014) and since then both I.H. and B.P. have been involved in more intensive surveys of various parts of the site. Most of this work has focused on Coleoptera and Hymenoptera, although other groups such as spiders and syrphids have been recorded at the same time. Further work has involved Butterfly Conservation, Buglife and individual surveyors. A wide range of survey methodologies has been employed here including general searching, pitfall trapping, sweep and "pond" netting, and pan, light and interception trapping, so that the resulting species list should give a good representation of what species are present.

A summary of the overall results to date is shown in Table 1. Only species whose conservation status is recognised as Red Data Book, Nationally Rare/Scarce or Nationally Notable (NA/NB) are included in the third column. The rarity statuses in different groups have been updated at a national level at different times and are not directly comparable. More general information on distribution, although to some extent subjective, has been obtained from the NBN Atlas, from local knowledge and from group specific publications and websites (e.g. www.bwars.com).

\section{INSECTA}

\section{Coleoptera}

With over 340 species of beetles having been recorded, Ardeer is the richest site for Coleoptera in Ayrshire. Given the wide range of habitats present, a correspondingly wide range of beetles would be expected.

\begin{tabular}{lll}
\hline Insect group & $\begin{array}{l}\text { Species } \\
\text { recorded }\end{array}$ & $\begin{array}{l}\text { Rare/Scarce } \\
\text { species }\end{array}$ \\
\hline Coleoptera & 341 & 22 \\
Lepidoptera & 216 & 4 \\
Hymenoptera & 132 & 3 \\
Diptera & 124 & 3 \\
Araneae & 103 & 4 \\
\hline
\end{tabular}

Table 1. Number of species of insects and arachnids recorded at Ardeer, North Ayrshire, Scotland, and the number whose conservation status is designated as Red Data Book, Nationally Rare/Scarce or Nationally Notable (NA/NB).

It is worthwhile looking at broad habitat types and highlighting those species that are recognised as rare or threatened at a UK level. It is important to note, however, that many species are significant because they are scarce in Scotland or because Ardeer represents an extension or new limit to their range.

Coastal

Ardeer supports two Nationally Rare sand dune specialists - Hypocaccus rugiceps and Orthocerus clavicornis (hairy-horned sand beetle) - and also boasts a first Scottish record for the Nationally Scarce carabid Harpalus neglectus (Philp \& Hamlin, 2018). Three other, more widespread dune species are the minotaur beetle Typhaeus typhoeus (Fig. 4) (Philp, 2018), the tenebrionid Phylan gibbus and Aegialia arenaria (dune chafer). These are fairly widespread in England and Wales but are much less common in Scotland with Ardeer being at the northern limit for the first two.

The estuary of the River Garnock has an area of SSSI saltmarsh and mud flats where two Nationally Scarce species occur: Phaedon concinnus, here near its northern limit, and Dyschirius politus.

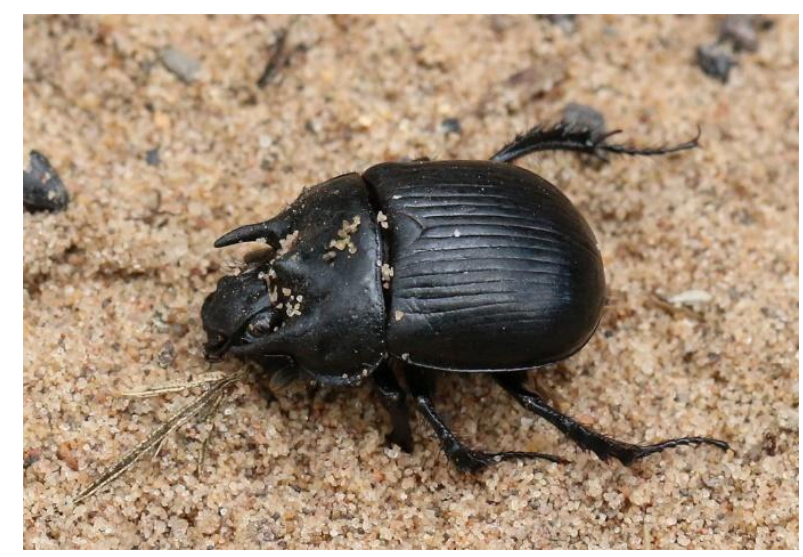

Fig. 4. Minotaur beetle (Typhaeus typhoeus) on Ardeer Peninsula, North Ayrshire, Scotland. (Photo: I. Hamlin)

\section{Grassland and Heath}

The dunes blend into fixed grassland and dune heath where $T$. typhoeus can still be found along with the ladybird Coccinella hieroglyphica, and then into permanent grassland further from the shore. Beetles of note here include Oedemera virescens (Nationally Rare), Tropiphorus terricola and Barynotus squamosus (both Notable B), Cassida nobilis (Nationally Scarce) 
and Olibrus aeneus, which is scarce in Scotland. All the grassland shows the influence of the sandy substrate, so that even fairly far from the shore species such as the weevil Andrion regensteinense are frequent.

\section{Wetland}

Ardeer has a range of wetland types from dune slacks through seasonal wetlands in former sand quarries to permanent wetland around the open water in Garnock West and East. A fairly large seasonally flooded former sand extraction area on the peninsula has a silty bottom and several specimens of the Nationally Scarce Stenolophus mixtus were found, the second site for the species in Scotland, and the furthest north. Also in this area were Blethisa multipunctata (Nationally Scarce), Gabrius osseticus (Notable B) and Agonum emarginatum, a scarce Scottish species.

Other areas of wetland support weevils such as the Notable B Grypus equiseti and Tournotaris bimaculatus, the latter being very scarce in Scotland. There is considerable scope for more detailed survey work in the extensive Garnock East area.

\section{Open Water}

There are large areas of open water on both sides of the River Garnock as a result of past industrial activity. Some of these ponds are well vegetated and hold water beetles nearing their northern limits such as Noterus clavicornis and Enochrus testaceus. As well as the truly aquatic species there are others that live in close association with water such as Donacia vulgaris, Limnobaris dolorosa, Scirtes hemisphaericus and Galerucella sagittariae.

In other areas there is more fen-like vegetation with Sphagnum spp. present. Among the commoner species here were a number of specimens of Nartus (formerly Rhantus) graptii. This is the second Scottish record for the species.

\section{Woodland}

Much of the woodland sampling has been in the pine plantations and this is reflected in the species list. The weevil Magdalis duplicata (Notable A) is a native pinewood specialist with only a few records outside its core range (Philp, 2017). Other pine specialists of note include the first Scottish record of the naturalised immigrant red longhorn beetle Stictoleptura rubra, the uncommon 18-spot ladybird (Myrra octodecimguttata) and the striped ladybird (Myzia oblongoguttata).

A number of saproxylic beetles have also been found. None has any national conservation status, but several are very local or scarce in Scotland. These include the sap feeders Omosita depressa and Soronia punctatissima, fungus feeders such as Dacne bipustulata, Sphaeriestes castaneus and Cis boleti, and wood borers such as Ptilinus pectinicornis (fan-bearing wood borer), Hylurgops palliatus, Hylastes brunneus and the introduced Euophryum confine.

\section{Hymenoptera}

Although the "Parasitica" and Symphyta have received little recording effort, significant attention has been paid to the aculeate hymenopterans on the peninsula. In large part because of its sandy substrate and bountiful supply of wildflowers, the site has the most diverse assemblage of bees and wasps in Scotland - 113 species.

\section{Coastal}

The peninsula is home to several coastal specialists. Colletes floralis, a pRDB species (likely to appear in the Red Data Book) associated with machair and sand dunes, is found commonly across much of the site. On the Ayrshire coast, $C$. floralis is kleptoparasitised by the cuckoo bee Epeolus cruciger. Scotland's first official record of E. cruciger pertains to a male caught nectaring on wild thyme (Thymus polytrichus) on the peninsula in July 2013

Colletes fodiens is known only in Scotland from the Ardeer area and Torrs Warren on the Solway coast. A very few discrete populations are dotted around the peninsula where there is an abundance of open sand and its forage source - ragwort (Senecio jacobaea) - is present in good quantities.

Other uncommon coastal specialists include the wasp Dryudella pinguis and the Nationally Scarce wasp Oxybelus mandibularis, which, along with the commoner $O$. uniglumis, is at the northern limit of its U.K. range at Ardeer.

The peninsula has several species now largely restricted to the coast following major declines inland, presumably as a result of the loss of wildflower-rich grasslands. These include the leaf-cutter bee Megachile circumcincta, and the mason wasp Ancistrocerus scoticus and its cuckoo Chrysis rutiliventris.

The site also supports several species that, although relatively widespread in England and Wales, are local and coastal in Scotland. These include the digger wasps Crabro peltarius and Tachysphex pompiliformis and the spider-hunting wasp Pompilus cinereus, all of which are on the Scottish Biodiversity List.

\section{Grassland and heath}

The peninsula supports a very diverse assemblage of aculeates associated with sandy grassland. Several rare wasp species have been recorded. A female Priocnemis schioedtei caught on a sandy track is one of the very few Scottish records of this Nationally Scarce spider-hunter. Similarly, a male Odynerus spinipes found in the same area represents the first modern Scottish record. Sandy pools at the site have produced several records of Anoplius concinnus, a wasp ecologically unusual in its association with wet areas, where it hunts wetland wolf spiders. Reflecting the abundance of spider-hunting wasps, the rare cuckoo spider-hunter Ceropales maculata has been recorded several times.

The large cuckoo bee Nomada flava was added to the site list in 2019. This appears to be the second Scottish 
record, following one caught at Carbarns, Lanarkshire in 2018 (Weddle, 2019). Other uncommon solitary bee species include the northernmost confirmed records of Lasioglossum fulvicorne and L. punctatissimum, and three species of yellow-faced bee: Hylaeus hyalinatus (Fig. 5), H. confusus and H. brevicornis.

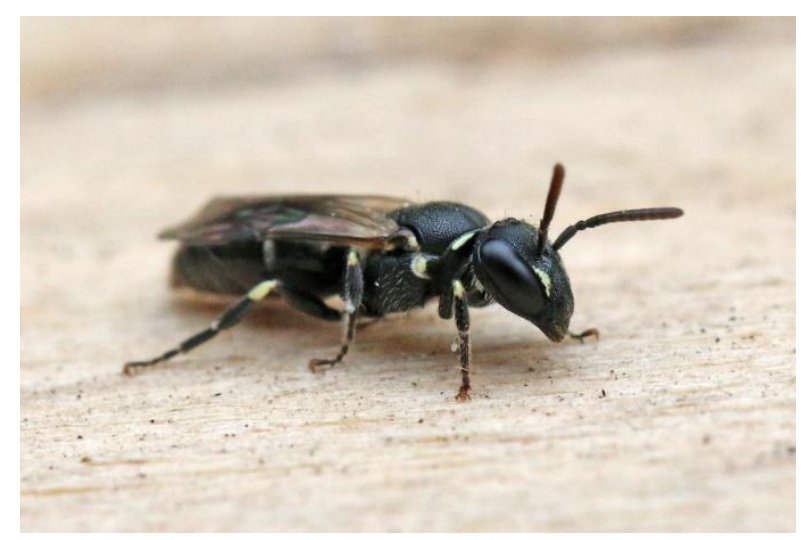

Fig. 5. Female yellow-faced bee Hylaeus hyalinatus. (Photo: I. Hamlin)

The extensive areas of dune heath at the site support an assemblage of local heathland bees, including Bombus jonellus, Colletes succinctus and Andrena fuscipes.

\section{Woodland}

Many of the species encountered in the peninsula's extensive woods do not have an ecological association with woodland, but simply make use of the sheltered, sandy tracks and clearings in the woods for nesting and foraging. However, several species rely on the woodland component of the site for breeding and feeding. The bountiful supply of deadwood throughout the wood provides ample nesting opportunities for solitary wasps. These include the Nationally Scarce Ectemnius ruficornis and Crossocerus leucostomus, both of which have a strong association with dead pine. The latter species was added to the site list in May 2018, when three males were found patrolling a fallen pine trunk.

The numerous willows (Salix spp.) that line the woodland edge and woodland tracks are an important foraging resource for several early solitary bees, including the RDB3 mining bee, Andrena ruficrus. Another uncommon "northern" mining bee - A. coitana - has been recorded at the site several times. It similarly displays a preference for scrubby woodland edge, where, amongst the tangle of bramble (Rubus fruticosus agg.) and small trees, it forages on thistles (Cirsium spp.) and knapweed (Centaurea nigra).

\section{Lepidoptera}

A total of 219 species of butterflies and moths has been recorded on the Ardeer Peninsula. Despite relatively little recording of moths having taken place, all the site's main habitat types have been surveyed.

\section{Coastal}

Some of the site's rarest moths are coastal specialists. Ayrshire's first record of the Nationally Scarce shore wainscot (Mythimna litoralis) pertains to two specimens caught on the peninsula in July 2018. Similarly, Ayrshire's first coast dart (Euxoa cursoria), another Nationally Scarce species, was trapped in dune heath several years earlier. Three local, coastal species abundant at the site are archer's dart (Agrotis vestigialis), white-line dart (Euxoa tritici) and straw underwing (Thalpophila matura). The last species, although widespread in England, has a patchy coastal distribution in Scotland. It is often the most abundant moth to be found in the seaward dunes in mid-summer.

The peninsula is the main Ayrshire site for dog's tooth (Lacanobia suasa), a species with a strong affinity for saltmarsh. All Ayrshire records come from the Ardeer area, most likely because the Garnock Estuary supports the only significant area of saltmarsh in the county.

Grayling (Hipparchia semele), a declining coastal butterfly, is present in large numbers throughout most of the site, especially where there are significant patches of open sandy ground and overgrown brownfield areas.

\section{Grassland and Heath}

In mid-summer, the peninsula's acid grassland is covered in a carpet of wild thyme. It is the only known Ayrshire site for the Nationally Scarce thyme pug (Eupithecia distinctaria). The local and declining hedge rustic (Tholera cespitis) has also been recorded several times.

Several uncommon grassland micro moths are present at the site, including the burdock conch (Aethes rubigana), Teleiopsis diffinis and Pancalia schwarzella. The Ardeer Peninsula is the only known Ayrshire site for the latter two species.

The peninsula supports the largest colony of dark green fritillary butterfly (Argynnis aglaja: Fig. 6) in North Ayrshire: dozens are on the wing in July. Small pearlbordered fritillary (Boloria selene) has been encountered at the site, although a colony has yet to be discovered.

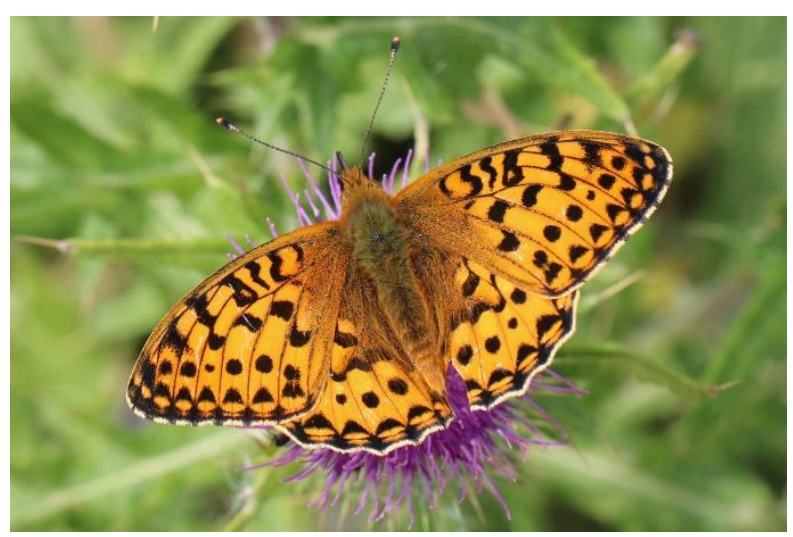

Fig. 6. Dark green fritillary Argynnis aglaja. (Photo: I. Hamlin)

The dune heath provides habitat for several uncommon heathland moths, including the anomalous (Stilbia 
anomala), heath rustic (Xestia agathina) and beautiful yellow underwing (Anarta myrtilli).

\section{Wetland}

Although the site's wetland habitats have received relatively little recording attention, several interesting wetland species have been found. These include the Nationally Scarce macro moth, marsh oblique-barred (Hypenodes humidalis) and the local micros beautiful china mark (Nymphula nitidulata) and shy cosmet moth (Limnaecia phragmitella).

\section{Woodland}

The peninsula's woodlands support an interesting assemblage of local species. Small yellow wave (Hydrelia flammeolaria), a scarce moth in Scotland, has been recorded twice on the peninsula. It is not clear which of its two main foodplants, sycamore and alder, it is utilising at the site. During the summer of 2019, a single scallop shell (Rheumaptera undulata), another local woodland specialist, was disturbed during the day from a wetland complex in the Black Powder Wood, where its foodplant, willow, grows in abundance. Other local woodland species include dark spectacle (Abrostola triplasia), scorched wing (Plagodis dolabraria), green silver-lines (Pseudoips prasinana) and the micro moth Carcina quercana.

A number of local moths associated with scrub have also been recorded. The Nationally Scarce broom-tip (Chesias rufata) is common in the extensive stretches of broom (Cytisus scoparius). Similarly, July belle (Scotopteryx luridata), a local gorse (Ulex europaeus) and broom feeder, has been found several times. Grass emerald (Pseudoterpna pruinata) and Chinese character (Cilix glaucata), two species largely restricted to the southwest are present in scrubby areas where their foodplants, gorse and hawthorn (Crataegus monogyna) and bramble respectively, are found. The local green longhorn moth Adela reaumurella has been observed in flight around woodland edge shrubs.

\section{Diptera}

Relatively little recording of Diptera has taken place at Ardeer. Data from two Buglife invertebrate surveys have been supplemented by other casual recording distributed across much of the rest of the site, leading to a site list totalling 124 species.

\section{Coastal}

Two Nationally Scarce sand dune specialists have been recorded. The sand dune hoverfly Eumerus sabulonum (Fig. 7) is commonly encountered at the site. In Britain its distribution is restricted to the west coast between Cornwall and Ayrshire. Phthiria pulicaria (flea bee-fly) can be locally abundant on yellow composites, such as hawkweeds (Hieracium spp.), in the dunes.

Other local coastal flies include the shore fly Philygria punctatonervosa, the sciomyzoid Heterocheila buccata, the muscid Helina protuberans, the satellite fly Senotainia conica and the robberfly Philonicus albiceps.
The last two species are towards the northern limit of their British range at Ardeer.

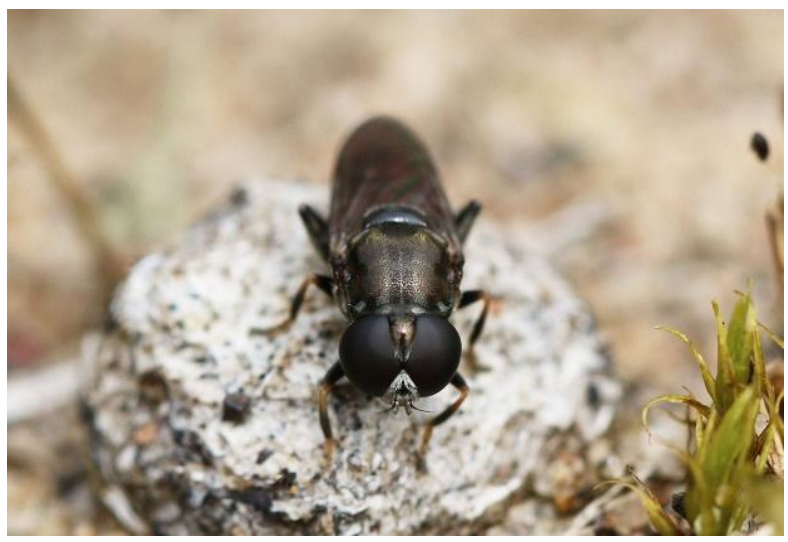

Fig. 7. The sand dune hoverfly Eumerus sabulonum. (Photo: I. Hamlin)

\section{Grassland and Heath}

The Nationally Scarce stilt-legged fly Micropeza lateralis has been found in scrubby acid dune grassland. Other local grassland species include the tachinid Appendicia truncata and Dysmachus trigonus (fanbristled robberfly). The latter species is particularly common at the site. The gall fly Tephritis formosa has a restricted range in Scotland and is near the northern limit of its British range at Ardeer.

\section{Woodland}

The woodland habitats at the site are some of the least studied, both in terms of flies and invertebrates more generally. However, the scarce deadwood hoverfly Criorhina ranunculi has been caught around sallow blossom in early spring, and the local hoverfly Chrysotoxum festivum has been encountered several times, especially where open areas are starting to be colonised by young birch. Nilea hortulana, a tachinid towards the northern limit of its range at Ardeer, has been recorded at the site.

\section{ARACHNIDA}

\section{Araneae}

Spiders at the Ardeer site have until recently received little attention, with nearby coastal sites such as Gailes and Shewalton being better known. The only known investigation before the present series was by staff of Glasgow Museums in 1988, who concentrated on the fixed dunes. Spiders were collected and identified by Dave Beaumont (pers. comm.). The 16 species found in 1988 are included here. Amongst these was then the first record for Scotland of the bridge orbweb spider Larinioides sclopetarius. More recently there have been collections by Buglife (Shanks, 2014), by B.P. in 2018 and 2019, and I.H. in 2019. The last two large collections were identified by A.L. The bulk of the recent sampling has been made using pitfall trapping, but the early records and some of the recent ones are based on hand collection. Pitfall trapping biases the collection in favour of ground-living active spiders, at the expense of species living higher in the vegetation column. 
Ninety one species of spiders have been found at Ardeer, five with national rarity designations, making it the second most species-rich site in Ayrshire after the Dalmellington/Sillyhole Moss complex sampled by Dave Curtis and students in 1977, where 92 species were recorded, 11 with national designations (Spider Recording Scheme, 2019; Curtis, 1977).

The spider community at Ardeer is dominated by members of the Lycosidae (wolf spiders), active hunters of open areas. Of the 30 species of Lycosidae found in Scotland, at least 15 have been found here. While pitfall trapping can overemphasise the importance of active hunters, the dominance of the group at $87 \%$ of the total catch and their large size indicate an ecosystem in which wolf spiders play the key role.

\section{Coastal}

Most of the spider interest of the site is in the coastal assemblages. The saltmarshes are dominated by the lycosid Pardosa purbeckensis, a species confined to the habitat. The Nationally Scarce sac-spider Cheiracanthium virescens is also confined to this habitat at Ardeer, though it is more usually found in dunes and heath. Three widespread species of lycosid - Pardosa monticola, Alopecosa pulverulenta and Trochosa ruricola - are found in this hostile habitat, along with small numbers of highly mobile Linyphiidae (money spiders) including Oedothorax fuscus and Erigone longipalpis, a species often found in saltmarshes.

Inshore from the saltmarsh, open sand and mobile dunes have a characteristic community dominated by the Nationally Scarce and southern Xerolycosa miniata and with Arctosa perita, both sand specialists. X. miniata (Fig. 8) has only one previous Ayrshire record, having been identified by the Glasgow naturalist Henry Young from spiders collected at Prestwick by F. Alexander in 1878, the first record of the species for Scotland (Young, 1879). The species is abundant here and this is the northernmost site on the west coast of the U.K., though it is found as far north as Angus on the east coast.

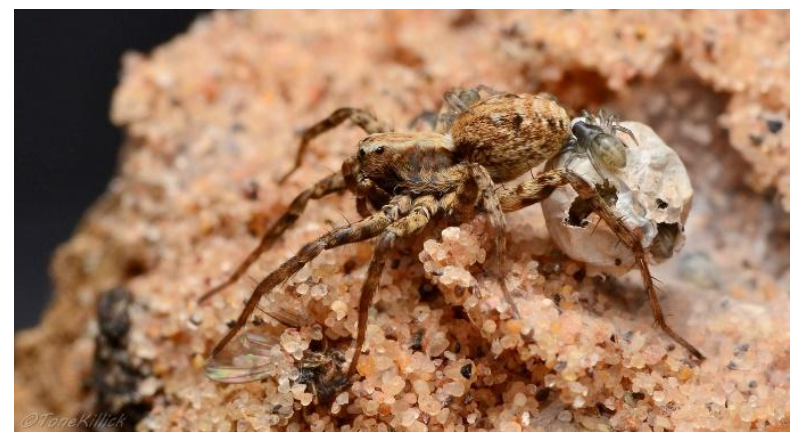

Fig. 8. The dune wolf-spider Xerolycosa miniata. (Photo: T. Killick)

Dunes dominated by marram grass (Ammophila arenaria) have large numbers of the Nationally Scarce Pardosa agrestis. The Nationally Scarce Scotina gracilipes was found in an open sand area, while the
1997 record for the characteristically southern species of orb web spider Hyposinga pygmaea was from fixed dunes, as was the 2018 record for the Nationally Scarce linyphiid Agyneta (formerly Meioneta) mossica.

Fixed dunes and dune slacks have a rich spider community, with more widespread lycosids such as Pardosa amentata, P. nigriceps and Pirata piraticus dominant. The orb web spinner, Agalenatea redii was found in dune slacks at its new northernmost site in the U.K. Walckenaeria unicornis, a mainly southern money spider (Linyphiidae), is one of several species of money spider found on Ardeer fixed dunes.

Ardeer is a striking example of a near complete set of spider communities characteristic of the gradient from sand and saltmarsh through dune habitats to heath, grassland and wetland.

\section{Grassland and heath}

Dune heath is home to Alopecosa barbipes, a species more typical of south coast heathland. The linyphiid Walckenaeria atrotibialis, a southern species of heath and calcareous grassland also occurs on Ardeer dune heath. Two large species of ground spiders (Gnaphosidae) - Drassodes cupreus and Haplodrassus signifier - while found in a range of Ardeer habitats, are commonest on dune heath. The distinctive gnaphosid Drassyllus pusillus was found in all coastal sites including saltmarsh and bare sand. In east Scotland and southern England this species is found in heathland and dry grassland, with related Drassyllus and Zelotes species in the more maritime habitats. None of the other species in this group has been found at Ardeer.

Dune grassland and improved pastures are dominated by the widespread lycosids Pardosa agrestis, P. pullata and Alopecosa pulverulenta, but it is also the habitat favoured by four species of crab spider (Thomisidae): Ozyptila trux, Xysticus cristatus, X. erraticus and the southern heathland species $X$. audax.

\section{Wetland}

Wetlands have not been well sampled, but the Typha swamp that was investigated was dominated by lycosids typical of wet habitats, including the characteristic pair Pardosa pullata and Pirata piraticus. Open water sites have not been sampled for spiders.

\section{Woodland}

A pine wood was the only woodland habitat that was sampled. Very few spiders were taken, though it contributed to the species list by providing the only records for some very widespread species, such as the near-ubiquitous linyphiids Tenuiphantes alacris and $T$. zimmermannii. No Lycosidae were found in the woodland.

Five species found at Ardeer are Nationally Scarce (Harvey et al., 2018). A high percentage of species $(16.5 \%$, i.e. $15 / 91)$ have characteristically southern distributions, in several cases at or near their most 
northerly U.K. site. A significant number of species are normally associated with southern heathland.

\section{Opiliones}

Ten species of harvestmen were found at Ardeer out of the total of 21 Scottish species. These include two new to Ayrshire: Mitostoma chrysomelas and Lacinius ephippiatus. All of the harvestman species found here are widespread and not considered to be of conservation concern.

\section{DISCUSSION}

In terms of its extent and variety, the suite of habitats present at Ardeer is unique in Ayrshire and probably in Scotland. The complex history of management on the site has meant that many of the original sand dune species, such as the hairy-horned sand beetle (Orthocerus clavicornis), the sand dune hoverfly Eumerus sabulonum and the northern colletes Colletes floralis, have survived. Furthermore, over a century of industrial interventions has brought in a wide range of new species and these reflect the wide variety of habitats: from unusual varieties of dune heath to huge areas of mixed and native woodland, and to complex wetland mosaics.

This diversity would be enough to highlight the importance of the site, but Ardeer's geographical location also makes it noteworthy. Ardeer is on the relatively sheltered and mild Clyde estuary and represents the northernmost large dune complex on the west coast mainland. Because of this, the site marks the northern limit for many species that have a southern distribution (e.g. the tenebrionid beetle Phylan gibbus, the yellow-faced bee Hylaeus brevicornis, and the gorse orb-weaver Agalenatea redii) and a very restricted distribution in Scotland. Crowson (1963) commented on the presence of southern species on the Solway and Ayrshire coasts, a fact which he thought had been previously overlooked.

The threats posed by the Special Development Order (SDO) and the Ayrshire Growth Deal are significant and made more so by the lack of any formal recognition of the site's importance. North Ayrshire Council has so far failed to add Ardeer to the list of Local Nature Conservation Sites in their Local Development Plan and Scottish Natural Heritage cannot consider the site for designation because of the SDO. A local Action Group, led by the Scottish Wildlife Trust but including Buglife, Butterfly Conservation, Plantlife and RSPB, has been set up to highlight the site's importance, to try to get the SDO revoked, and to ensure that any plans proposed as part of the Growth Deal are subject to a full Strategic Environmental Assessment.

\section{ACKNOWLEDGEMENTS}

Many people have contributed to the survey work at Ardeer. Suzanne Burgess (Buglife), Scott Donaldson (Butterfly Conservation), Geoff Hancock, Gill Smart (Scottish Wildlife Trust), Richard Weddle (Glasgow Museums Biological Records Centre) and Toby Wilson (RSPB), have been particularly helpful, and Paul Cobb has contributed many invertebrate records. Roger Hissett has led the local action group and kept up the momentum to safeguard this unique site.

\section{REFERENCES}

Blaeu, W.J. (1654). https://maps.nls.uk/00000422

Clements, J. (1974). Stevenston: The Kernel of Cunninghame. The Burgh of Stevenston.

Crowson, R.A. (1963). Observations on insects and arachnids from the Scottish south coast. The Glasgow Naturalist 18(5), 228-232.

Curtis, D.J. (1977). Lowland Bogs Spider Survey 1977. Nature Conservancy Council, Balloch.

Dargie, T.C.D. (1998). Sand Dune Vegetation Survey of Scotland: South West. Volume 2: Site Reports. SNH Research, Survey and Monitoring Report No. 125. Edinburgh, Scottish Natural Hritage.

Dargie, T.C.D. (2000). Ardeer Proposed Windfarm Development Phase 1. Habitat and NVC Survey.

Dolan, J.E. \& Oglethorpe, M.K. (1996). Explosives in the Service of Man. Ardeer and the Nobel Heritage. RCAHMS, Edinburgh.

Harvey, P., Davidson, M., Dawson, I., Fowles, A., Hitchcock, G., Lee, P. et al. (2017). A Review of the Scarce and Threatened Spiders (Araneae) of Great Britain: Species Status No. 22. Natural Resources Wales, Bangor.

Ordnance Survey (1860). Sheet XVI. https://maps.nls.uk/view/74425803 Accessed 28th October 2019.

Philp, B. \& Hamlin, I. (2016). Recent insect records from North Ayrshire's sand dune systems. The Glasgow Naturalist 26(3), 74-79.

Philp, B. (2017). Magdalis duplicata Germar (Curculionidae) new to Ayrshire. The Coleopterist 26(2), 122.

Philp, B. (2018). Typhaeus typhoeus (Linnaeus) (Geotrupidae) in Scotland. The Coleopterist 27(2), 97-101.

Philp, B. \& Hamlin, I. (2018). Harpalus neglectus (Audinet-Serville) (Carabidae) new to Scotland. The Coleopterist 27(3), 132-133.

Shanks, S. (2014). A Survey of the Pollinators and other Insects of Garnock West, Ardeer, Stevenston, Ayrshire. Buglife, Stirling.

Spider Recording Scheme (2019). Spider Recording Scheme. British Arachnological Society. http://srs.britishspiders.org.uk Accessed 1st November 2019.

Trotter, R. (1938). The History of Nobel's Explosives Company Limited and Nobel Industries Limited, 1871-1926. Imperial Chemical Industries, London.

Weddle, R.B. (2019). Nomada flava (Hymenoptera: Apidae): first confirmed Scottish record. The Glasgow Naturalist 27(1), 88-89.

Woodrow, J. (1793). Statistical Account of Scotland: Part VII. Number 1. Parish of Stevenston. Statistical Account of Scotland, Edinburgh.

Young, H.C. (1879). Specimens exhibited. April 29th, 1879. Proceedings of the Natural History Society of Glasgow 4, 78-79. 